\title{
Efficiency and energy modelling for PVT air collector with extended heat transfer area: a review
}

\author{
Ahmad Fudholi ${ }^{1}$, Mariyam Fazleena Musthafa ${ }^{2}$, Ivan Taslim ${ }^{3}$, Merita Ayu Indrianti ${ }^{4}$, \\ Intan Noviantari Manyoe ${ }^{5}$, Mohd. Yusof Othman ${ }^{6}$ \\ 1, 2, ${ }^{6}$ Solar Energy Research Institute, Universiti Kebangsaan Malaysia, Malaysia \\ ${ }^{3,4}$ Universitas Muhammadiyah Gorontalo, Indonesia \\ ${ }^{5}$ Universitas Negeri Gorontalo, Indonesia
}

\begin{abstract}
Article Info
Article history:

Received Nov 19, 2018

Revised Feb 12, 2019

Accepted Apr 7, 2019

\section{Keywords:}

Renewable energy

Thermal modelling

Photovoltaic

Thermal

Solar collector
\end{abstract}

\begin{abstract}
Solar energy is renewable and environment friendly and has been widely used in electricity generation and thermal energy through photovoltaic thermal (PVT) system. This system is beneficial in terms of maximum energy generation and cost of usage. The growing concern on energy sources and their usage has increased the significance and demand for PVT collectors. A PVT air collector consists of a PV panel and a thermal collector system. In PVT air collector, electricity and thermal energy are generated simultaneously. This review focuses on efficiency and energy modelling for PVT air collector with extended heat transfer area. Findings of this review indicated that PVT air collector with extended heat transfer area produced PVT efficiency higher than conventional PVT air collector. The thermal efficiency of PVT air collector for with and without extended heat transfer area are $21-83 \%$ and $12-70 \%$, respectively, which the improvement of thermal efficiency is $15.7-42.8 \%$.
\end{abstract}

Copyright (C) 2019 Institute of Advanced Engineering and Science. All rights reserved.

\section{Corresponding Author:}

Ivan Taslim,

Universitas Muhammadiyah Gorontalo, Indonesia.

Email: ivantaslim@umgo.ac.id

\section{INTRODUCTION}

Energy is a key requirement for undergoing and performing work. Around the 20th century, the demand and energy consumption have increased, and the primary energy source is fossil fuels. At present, the world energy consumption is expected to continuously grow. However, fossil fuel reserves are limited and may not meet the energy demand in the future. In addition, the release of green gas resulting from excessive fossil fuel combustion releases greenhouse gases and causes global climate change. Hence, fossil fuel is an unsustainable energy source. At present, using energy from renewable resources is a key factor in improving and adding benefits to the society because it is sustainable. Solar energy is radiation produced by nuclear fusion and is radiated from the sun in all directions. Solar energy beamed onto the Earth for even an hour is sufficient to produce the global energy need for an entire year. Many technologies are available for harnessing energy from the sun, and such energy can be used in two forms, namely, thermal and electrical energy. Photovoltaic thermal (PVT) technology utilizes radiation from solar energy to produce electrical and thermal energy. This technology consists of a PVT collector, which is a hybrid system that deploys solar PV and solar heater. The solar cell temperature increases when the PV panel is irradiated with solar energy. The higher the difference between the ambient temperature and the temperature of the cell is, the lower the electrical efficiency and electrical output of the PV panel will be. The electrical efficiency can be enhanced through heat extraction by passing a heat-extracting fluid (air or water) under the module. This integrated method, where electrical and thermal energy are generated simultaneously, is the basis of PVT collectors [111]. Aste et al. [12] validated a simulation model proposed by Aste et al. [13] based mainly on three balance 
equations for the collector sub-systems and two equations for the storage tank, organized in matrix form. Moreover, a system of five additional equations for the dynamic calculation of the convective and radiative coefficients was solved by means of an iterative procedure. The difference between the experimental data and simulated data were found to be only a few percentage points.

The major advantages of using PVT are as follows: (i) It has a dual-purpose, that is, it can produce electricity and heat; (ii) it is efficient and flexible, the combined efficiency is higher than that of using two individual systems and is especially attractive when roof-panel spacing is limited; (iii) it has wide application prospects, where the heat output is important for heating and cooling (desiccant cooling) applications depending on the season and is suitable for domestic applications; and (iv) it is cheap and practical and can be easily integrated to the building with minor modification. Furthermore, replacing the roofing material with the PVT can reduce the payback period.

The main components of PVT collectors are a PV panel on the top for converting solar radiation into electrical energy, an absorber plate and insulators at the bottom of the collector. The thermal absorber underneath the panel captures remaining energy and removes excessive heat from the panel. The overall performance of PVT air collectors can be evaluated through thermodynamic, environmental and economic impact analyses. Enviro-economic and exergo-economic analyses of PVT air collectors were also conducted. Scholars or researchers have also studied energy-exergy-economic-environmental analyses of different PVT systems [14-17]. Tripathi et al. [17] states with regard to the energy loss factor during the transmission and distribution process in the supply energy, estimated $\mathrm{CO}_{2}$ emission rate per $\mathrm{kWh}$ is $2.08 \mathrm{~kg}$. They conducted studies on energy, energy and carbon analysis on solar collector PVT systems that were in a shielded part connected in series. The study was conducted by placing solar collectors on four conditions with different solar collector protection rates of $25 \%, 50 \%, 75 \%$ and $100 \%$ in New Delhi. In this review, we focused on the efficiency and energy modelling for PVT air collector with extended heat transfer area.

\section{STUDIES CONDUCTED ON PVT AIR COLLECTORS}

\subsection{Conventional PVT air collector}

Joshi \& Tiwari [18] carried out an energy and exergy analysis of a PVT parallel plate air collector for the cold climate region of India (Srinagar). They reported that the PVT air collector had instantaneous energy and exergy efficiencies of $55 \%-65 \%$ and $12 \%-15 \%$, respectively. Dubey et al. [19] conducted an exergy analysis of a PVT system with two configurations of air collector, namely, Case I (air collector is fully covered by PV module [glass-to-glass], and air flows above the absorber plate) and Case II (air collector is fully covered by PV module [glass-to-glass], and air flows below the absorber plate). A detailed analysis of exergy for the configuration of collectors concluded that the design of Case II is advantageous in terms of hot air production and electricity generation. For Case II, the daily useful heat gain increased with increasing number of collectors due to the high operating temperature. In addition, at low air velocity, the daily useful heat gain increased for Case II and became nearly the same for higher velocity due to the low operating temperatures; hence, upward thermal losses decreased.

Tonui and Tripanagnostopoulos [20] studied the effect of induced mass flow rate on glazed and unglazed PVT prototype models. The induced mass flow rate increased with increasing solar radiation due to more irradiance intercepted by the PVT collector. This phenomenon increased the heat energy transfer to the air flow in the channel, which in turn increased the output temperature and created a high stack effect. Moreover, the induced mass flow rate was high at low ambient or inlet temperature and at a large tilt angle because the temperature increase was greater at low inlet temperatures than at high inlet temperatures. These results are significant for PVT applications operated in four-seasonal countries, where high and low flow rates are anticipated in winter and summer, respectively. In summer, the flow rate may be improved by installing a small fan and using a small amount of electricity produced from the PV to power the fan. In winter, the fan may be switched off to use all of the electricity generated from the PV for other applications in the building.

Hegazy [21] comprehensively investigated the overall performances of flat plate PVT air collectors. This investigation was based on single glazing collectors, where air flows over the absorber (Model I) or below it (Model II) and on both sides of the absorber in a single pass (Model III) or in a double pass (Model IV). The results concluded that for a given collector design, the temperature of the PV decreases due to an increase in flow rate, thereby improving the electrical efficiency of the collector. Among the four PVT models, Model 1 displayed the lowest overall performance, whereas Model III exhibited the highest overall performance, followed by Model IV. The flow channel ratio D/L, where $\mathrm{L}$ is the effective absorber area of the length and $\mathrm{D}$ is the depth of the flow channel, was found to be an important design parameter. The ratio must be equal to $2.5 \times 10^{-3}$ to achieve the optimal thermoelectric efficiency. In addition, this study revealed that the use of selective absorber plates in such types of PVT collectors reduced the electricity generated by

Int J Pow Elec \& Dri Syst Vol. 10, No. 4, Dec 2019 : 2029 - 2036 
PV. Therefore, Model III PVT collector was identified as the most suitable design for converting solar energy into low-quality heat and high-quality electrical energy.

Tripanagnostopoulos et al. [22] experimentally analysed the performance and cost and life cycle of PVT air collector systems with glazed and unglazed collectors. Thin fill metallic sheet (TFMS) modification in the air channel increased the combined electrical and thermal energy output compared with that in an unglazed PVT air collector. The modification also produced a higher electrical output than that in a glazed PVT. Furthermore, the electrical output of the PVT was higher than that of the standard PV for only the titled unglazed PVT and the titled PVT with TFMS. The calculated thermal output for the heated air for 6 months was nearly $40 \%$ of that from the reference mode of 12 months.

Bambrook and Sproul [23] conducted an experiment to maximise the energy output of a PVT system under the Sydney climate. As the air mass flow rate increased, the thermal efficiency values increased, approaching the maximum value of around $55 \%-60 \%$. Although this thermal efficiency seems very good, the increase in the air temperature from the inlet to the outlet was very small at higher air flow rates. The reason is that when the air flow velocity increases, air has less time inside the channel to attain higher outlet temperatures.

Tonui and Tripanagnostopoulos [24] investigated and validated how the heat extraction of PVT air collectors can be increased while maintaining the electrical efficiency at an acceptable level. The results revealed that the energy efficiencies for finned, suspended metallic plate and normal air heaters were $30 \%$, $28 \%$ and $25 \%$, respectively. They also developed a similar model to validate the PV module temperature, back wall temperature and air outlet temperature of PVT configurations by using thin flat metal sheets suspended in the middle or at the finned back wall of an air channel in the PVT. This model predicted the temperatures within an error of approximately $\pm 2{ }^{\circ} \mathrm{C}$ on average for all measured temperatures. They have also analysed the effect of glazing. Several studies on the energy and exergy analyses on PVT air collectors are listed in Table 1.

Table 1. Studies conducted on PVT air collectors

\begin{tabular}{|c|c|c|c|c|c|}
\hline \multirow{2}{*}{ Author(s) } & \multirow{2}{*}{ Study } & \multicolumn{3}{|c|}{ Energy efficiency (\%) } & \multirow{2}{*}{$\begin{array}{l}\text { PVT } \\
\text { exergy efficiency }\end{array}$} \\
\hline & & PVT & $\mathrm{PV}$ & Thermal & \\
\hline $\begin{array}{l}\text { Tonui \& Tripanagnostopoulos } \\
{[24]^{*}}\end{array}$ & $\begin{array}{l}\text { Theoretical and } \\
\text { experimental }\end{array}$ & $61-62$ & $9-10$ & 52 & - \\
\hline Slimani, et al. [25] & $\begin{array}{l}\text { Theoretical and } \\
\text { experimental }\end{array}$ & 90 & 10.5 & 70 & - \\
\hline Gholampour \& M. Ameri [26] & $\begin{array}{l}\text { Theoretical and } \\
\text { experimental }\end{array}$ & $54-70$ & - & $45-55$ & $4.35-8.66$ \\
\hline Rajoria, et al. [27] & Experimental & - & $3.1-9.1$ & $12.1-28.1$ & - \\
\hline Amori \& Abd-AlRaheem [28] & Experimental & - & $8.3-10.4$ & $46-62$ & - \\
\hline Rajoria, et al. [29] & $\begin{array}{l}\text { Theoretical and } \\
\text { experimental }\end{array}$ & - & - & - & 16.3 \\
\hline Amori, \& Al-Najjar [30] & Theoretical & $47.8-53.6$ & $9-12.3$ & $19.4-22.8$ & - \\
\hline Agrawal, et al. [31] & $\begin{array}{l}\text { Theoretical and } \\
\text { experimental }\end{array}$ & - & 12.4 & 35.7 & - \\
\hline Sarhaddi, et al. [32] & $\begin{array}{l}\text { Theoretical and } \\
\text { experimental }\end{array}$ & - & 7.13 & 33.54 & - \\
\hline Agrawal \& Tiwari [33] & Experimental & 45 & 10 & 17.18 & 10.75 \\
\hline Agrawal \& Tiwari [34] & Experimental & 53.7 & - & - & - \\
\hline Sarhaddi, et al. [35] & $\begin{array}{l}\text { Theoretical and } \\
\text { experimental }\end{array}$ & 45 & 10 & 17.18 & - \\
\hline Fudholi, et al. [36] & $\begin{array}{l}\text { Theoretical and } \\
\text { experimental }\end{array}$ & $31.21-94.24$ & $9.87-11.34$ & $21.3-82.9$ & $12.66-12.91$ \\
\hline Othman, et al. [37] & $\begin{array}{l}\text { Theoretical and } \\
\text { experimental }\end{array}$ & $39-70$ & - & - & - \\
\hline Mojumder et al. [39]* & $\begin{array}{l}\text { Theoretical and } \\
\text { experimental }\end{array}$ & - & 13.8 & 56.2 & - \\
\hline I. Tabet, et al. [40] $]^{*}$ & $\begin{array}{l}\text { Theoretical and } \\
\text { experimental }\end{array}$ & - & 10 & $22-78$ & - \\
\hline Rosa-Clot, et al. [41] & Experimental & - & 13.2 & 62 & - \\
\hline Tiwari and Tiwari [42] & $\begin{array}{l}\text { Theoretical and } \\
\text { experimental }\end{array}$ & 68.5 & - & - & - \\
\hline B. Das, et al. [43] & Experimental & $72-83$ & $13.5-14.6$ & - & $16.4-16.6$ \\
\hline Abdullah, et al. [44] & Theoretical & $35-56$ & $7-15$ & $5-20$ & - \\
\hline
\end{tabular}




\subsection{PVT air collector with extended heat transfer area}

Tonui and Tripanagnostopoulos [24] posited that compared with an unglazed system, a glazed air collector system exhibited higher thermal efficiency because of the reduced heat losses and the lower electrical efficiency as a result of increased absorption and reflection losses in the glass cover and the higher PV module temperature. In addition, Tonui and Tripanagnostopoulos [24] proved that the air outlet temperature decreased with increasing channel depth. The fin system results produced outlet temperature higher than those of the TMS and conventional air collector systems for any channel depth. The increased heat extraction by the fins and the TMS system provides a slightly higher outlet temperature than that of the conventional air collector system because of the increased heat exchange surface. In addition, the thermal and electrical efficiencies decreased with increasing channel depth. The thermal efficiency decreased because of the reduced flow rate, whereas the electrical efficiency decreased because of the increase in the PV temperature as the depth increased. The fin system exhibited better thermal and electrical performance than the two other systems. Compared with the conventional air collector system, the TMS system provided a better thermal energy but only a marginally better electrical efficiency.

\section{MATHEMATICAL MODEL OF PVT AIR COLLECTORS WITH EXTENDED HEAT TRANSFER AREA}

A PVT air collector consists of a conventional PV panel and a thermal collector system. The system can produce electrical energy directly converted from sunlight by using the photoelectric effect, extract heat from the PV panel and warm the air flow inside the collector. PVT collectors maximize the use of solar energy due to their dual functions and have higher overall solar conversion rate than that PV or solar collector alone. The PV cells are composed of semiconductor materials that convert the high-energy photons of incident solar radiation into electricity. Low-energy photons are absorbed by the PV panel and generate heat within the cells. The generation of heat within the cell reduces the efficiency of the cells. The PVT collector extracts a great portion of the heat for practical applications. The removal of heat from the cell and transferring it to the working fluid increase the electrical efficiency of the PV panel while simultaneously producing hot fluid for thermal applications. PVT offers an improved method of utilizing solar energy and leads to high overall efficiency of the system. One way to enhance the collector's efficiency of PVT air collector is use heat transfer area through absorbers. Fig. 1 shows the three types of PVT air collectors with extended heat transfer area.

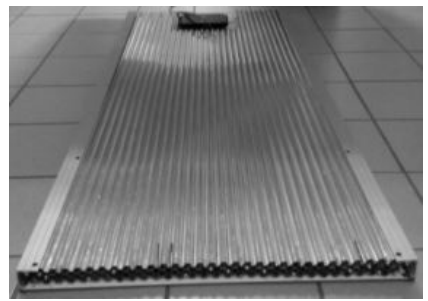

(a)

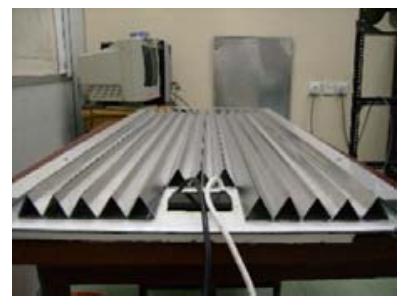

(b)

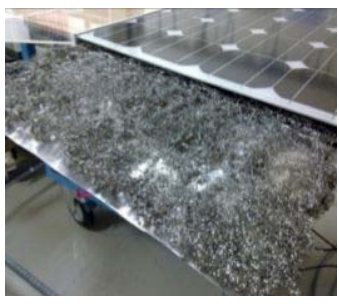

(c)

Figure 1. Photograph of extended heat transfer area installed at the back of PV panel, (a) honeycomb absorber, (b) $\nabla$-groove absorber, and (c) stainless porous media absorber

In 2018, Fudholi et al. [36] theoretically and experimentally studied PVT air collectors with $\nabla$ groove, as shown in Fig. 1(b) and Fig.2. The steady-state energy balance equations for PVT air collectors with $\nabla$-groove are expressed as follows.

For PV:

$$
\tau \alpha G=U_{t}\left(T_{p}-T_{a}\right)+h_{1}\left(T_{p}-T_{f}\right)+h_{r p b}\left(T_{p}-T_{b}\right)+\eta_{p} G+Q_{n}
$$

For the air flow channel:

$$
m C\left(T_{o}-T_{i}\right)=h_{1}\left(T_{p}-T_{f}\right)+h_{2}\left(T_{b}-T_{f}\right)+Q_{n}
$$

For the back plate: 


$$
h_{r p b}\left(T_{p}-T_{b}\right)=h_{2}\left(T_{b}-T_{f}\right)+U_{b}\left(T_{b}-T_{a}\right),
$$

where

$$
\begin{aligned}
& Q_{n}=N A_{n} h_{c} \eta_{n}\left(T_{p}-T_{f}\right), \\
& \eta_{n}=\frac{\tanh M H}{M H}, \\
& \text { and } M=\left(\frac{2 h_{c} l}{k_{n} A_{c n}}\right)^{1 / 2}
\end{aligned}
$$

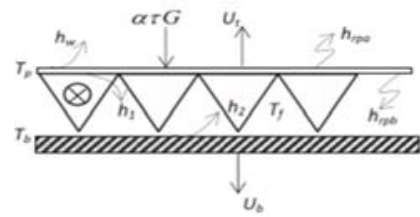

Figure 2. Schematic of heat transfer characteristics of PVT air collector with $\nabla$-groove

Tonui et al. [24] determined the performance of two low-cost heat removal enhancements in the channel of a PVT air system to obtain a high thermal output and PV cooling and improve electrical efficiency. The recommended method used a flat TMS deferred at the middle or a finned back wall in the PVT air system. The energy balance of the PVT air collector is shown in Fig. 3.

For the back wall fin system, the energy balance is expressed as follows.

For the glass cover:

$$
A_{p v}\left(h_{r, p v g}-h_{c}^{\prime}\right)\left(T_{p v}-T_{g}\right)=A_{p v}\left(h_{r, g a}+h_{w}\right)\left(T_{g}-T_{a}\right)
$$

For the fluid:

$$
\dot{m} C_{p}\left(T_{o}-T_{i}\right)=A_{p v} h_{c}\left(T_{p v}-T_{f}\right)+A_{i n t} h_{c}\left(T_{w}-T_{f}\right)+N \int_{z=0}^{z=H} 2 h_{c} L\left(T_{f i n}-T_{f}\right) d z
$$

For the back wall:

$$
A_{p v} h_{r, p v w}\left(T_{p v}-T_{w}\right)=A_{p v} U_{b}\left(T_{w}-T_{a}\right)+A_{i n t} h_{c}\left(T_{w}-T_{f}\right)+N\left(-k A_{c f} \frac{d T_{f i n}}{d z}\right)
$$

For the fin:

$$
\left.N\left(-k A_{c f} \frac{d T_{f i n}}{d z}\right)\right|_{z=0}=N \int_{z=0}^{z=H} 2 h_{c} L\left(T_{f i n}-T_{f}\right) d z
$$

(b)

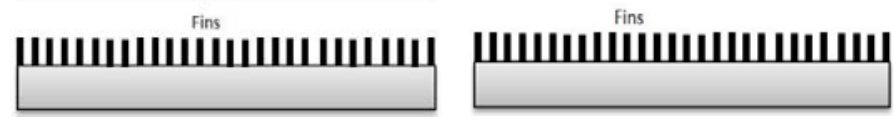

(a)

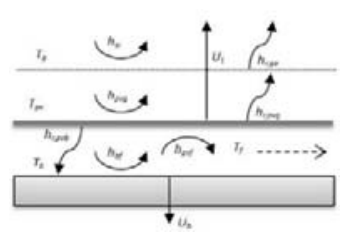

(c)

Figure 3. Various PVT systems with and without glass (a) PVT/air-Fin+UGL, (b) PVT/air-Fin+GL and (c) PVT/air-REF+GL system 
Othman et al. [37, 38] examined electricity and heat energy with a double-pass PVT air collector with fin. Fin was used to increase the overall of efficiency of the double-pass PVT air collector. The energy balance of this PVT air collector, as shown in Fig. 4, is expressed as follows. They concluded that important to use fins as an integral part of the absorber surface in order to achieve meaningful efficiencies for both electrical and thermal output of the PVT air collector.

For the glass cover:

$$
\alpha_{g} I=h_{r g s}\left(T_{g}-T_{s}\right)+h_{g w}\left(T_{g}-T_{w}\right)+h_{g f 1}\left(T_{g}-T_{f 1}\right)+h_{r, g p}\left(T_{g}-T_{p}\right)
$$

For the first air channel:

$$
\frac{\dot{m} C_{f 1}}{W} \frac{d T_{f 1}}{d x}=h_{g f 1}\left(T_{g}-T_{f 1}\right)+h_{p f 1}\left(T_{p}-T_{f 1}\right)
$$

For the absorber plate containing the PV module and fins:

$$
\begin{aligned}
& \tau_{g} \alpha_{p} I(1-F)+\tau_{g} \alpha_{p v} I F\left(1-\eta_{p v}\right)=h_{p f 1}\left(T_{p}-T_{f 1}\right)+h_{r, p g}\left(T_{p}-T_{g}\right)+h_{p f 2} \frac{A_{a b r}}{A_{c}} \eta_{p}\left(T_{p}-\right. \\
& \left.T_{f 2}\right)+h_{r p b} \frac{A_{a b r}}{A_{c}}\left(T_{p}-T_{b}\right)
\end{aligned}
$$

For the second air channel:

$$
\frac{\dot{m} C_{f 2}}{W} \frac{d T_{f 2}}{d x}=h_{p f 2} \frac{A_{a b r}}{A_{c}} \eta_{p}\left(T_{p}-T_{f 2}\right)+h_{b f 2}\left(T_{b}-T_{f 2}\right)
$$

For the bottom plate:

$$
h_{b f 2}\left(T_{f 2}-T_{b}\right)+h_{r, p b} \frac{A_{a b r}}{A_{c}}\left(T_{p}-T_{b}\right)=U_{b}\left(T_{b}-T_{a}\right)
$$

The variables $T_{g}, T_{p}$ and $T_{b}$ can be eliminated from Eqs. (12) and (14) by substituting Eqs. (11)-(13) into them. Then will get two linear first-order differential equations were obtained.

(a)

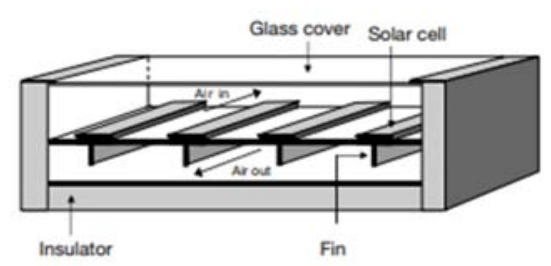

(b)

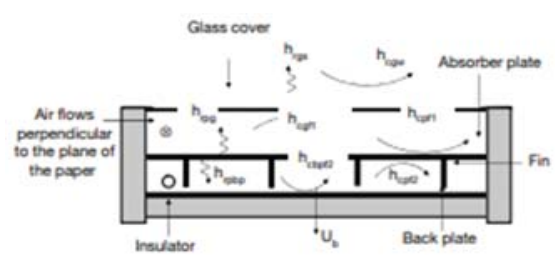

Figure 4. (a) Schematic model of a double-pass PVT air collector with fin, (b) The thermal schematic model of a double-pass PVT air collector with fin [37]

\section{CONCLUSIONS}

This review concludes that a number of research have been conducted on PVT air collectors to explore efficiency enhancements by design development, numerical simulation, prototype design, experimental testing and testing methodologies for PVT air collectors. The energy and exergy efficiencies of PVT air collectors with extended heat transfer area were $39 \%-94 \%$ and $12.66 \%-12.91 \%$, respectively. The efficiencies vary because of differences in the heat transfer area through the absorber (finned absorber and corrugated surfaces), design and air flow configuration (single-pass and double-pass; with and without glass cover). Generally, the steady-state energy balance equations using to mathematical modelling of PVT air collector with extended heat transfer area. In addition, linear first-order differential equations were reported for solution of mathematical model.

Int J Pow Elec \& Dri Syst Vol. 10, No. 4, Dec 2019 : 2029 - 2036 


\section{ACKNOWLEDGEMENTS}

We gratefully acknowledge the funding from USAID through the SHERA program-Centre for Development of Sustainable Region (CDSR). In year 2017-2021 CDSR is led by Center for Energy StudiesUGM.

\section{REFERENCES}

[1] M. Mustapha, et al., "Review on energy and exergy analysis of air and water based photovoltaic thermal (PVT) collector, "International Journal of Power Electronics and Drive Systems (IJPEDS), 9 (3), pp. 1383-1389, 2018.

[2] N.S. Nazri et al., "Mathematical modeling of photovoltaic thermal-thermoelectric (PVT-TE) air collector. International Journal of Power Electronics and Drive Systems (IJPEDS), 9 (2), pp. 795-802, 2018.

[3] N.S. Nazri, "Experimental study of photovoltaic thermal-thermoelectric (PVT-TE) air collector," International Journal of Power Electronics and Drive Systems (IJPEDS), 9 (3), pp. 1406-1412, 2018.

[4] M. Zohri et al., "Photovoltaic thermal (PVT) system with and without fins collector: theoretical approach," International Journal of Power Electronics and Drive System (IJPEDS) 8(4), pp. 1756-63, 2017.

[5] M. Zohri, et al., "Exergy assessment of photovoltaic thermal with v-groove collector using theoretical study," TELKOMNIKA 16(2), pp. 550-57, 2018.

[6] [A. Fudholi et al., "R\&D of Photovoltaic Thermal (PVT) Systems: an overview," International Journal of Power Electronics and Drive Systems (IJPEDS) 9 (2), pp. 803-10, 2018.

[7] A. Fudholi, et al., "Performance analysis of photovoltaic thermal (PVT) water collectors,"Energy Conversion and Management, vol. 78, pp. 641-651, 2014.

[8] A. Fudholi, et al., "Collector efficiency of the double-pass solar air collectors with fins," Proceedings of the 9th WSEAS International Conference on SYSTEM SCIENCE and SIMULATION in ENGINEERING (ICOSSSE'10), Japan, 2010, pp. 428-34.

[9] A. Fudholi, et al., "Experimental Study of the double-pass solar air collector with staggered fins," Proceedings of the 9th WSEAS International Conference on SYSTEM SCIENCE and SIMULATION in ENGINEERING (ICOSSSE'10), Japan, 2010, pp. 410-14.

[10] A. Fudholi, et al., "Review of solar photovoltaic/thermal (PV/T) air collector," International Journal of Electrical and Computer Engineering (IJECE) 9 (1), pp. 126-133, 2019.

[11] N.F.M. Razali et al., "Experiment study of water based photovoltaic-thermal (PV/T) collector," International Journal of Electrical and Computer Engineering (IJECE) 9(1), pp. 118-125, 2019.

[12] N. Aste, C. Del Pero, F. Leonforte, and M. Manfren, "Performance monitoring and modeling of an uncovered photovoltaic-thermal (PVT) water collector," Solar Energy, vol. 135, pp. 551-568, 2016.

[13] N. Aste, F. Leonforte, and C. Del Pero, "Simulation and model validation of uncovered PVT solar system," 4th International Conference on Clean Electrical Power: Renewable Energy Resources Impact, ICCEP 2013, pp. 789 $795,2013$.

[14] Shyam and G.N. Tiwari, "Analysis of series connected photovoltaic thermal air collectors partially covered by semitransparent photovoltaic module", Solar Energy, vol. 137, pp. 137:452-462, 2016.

[15] C.S. Rajoria, et al., "A Novel investigation of building integrated photovoltaic thermal (BiPVT) system: a comparative study. Solar Energy, vol. 131, pp. 107-118, 2016.

[16] C.S. Rajoria, et al.,"A newer approach on cash flow diagram to investigate the effect of energy payback time and earned carbon credits on life cycle cost of different photovoltaic thermal array systems", Solar Energy, vol. 124, pp. 124:254-267, 2016.

[17] R. Tripathi, et al., "Overall energy, exergy and carbon credit analysis of N partially covered photovoltaic thermal (PVT) concentrating collector connected in series," Solar Energy, vol. 136, pp. 260-267, 2016.

[18] A.S. Joshi and A. Tiwari, "Energy and exergy efficiencies of a hybrid photovoltaic-thermal (PV/T) air collector," Renewable Energy, vol. 32, no.13, pp. 2223-41, 2007.

[19] S. Dubey, et al., "Energy and exergy analysis of PV/T air collectors connected in series," Energy and Buildings, vol. 41, no.8, pp. 863-70, 2009.

[20] J.K. Tonui and Y. Tripanagnostopoulos, "Performance improvement of PV/T solar collectors with natural air flow operation,"Solar Energy, vol. 82, no.1, pp. 1-12, 2008.

[21] A. Hegazy, et al., "Comparative study of the performances of four photovoltaic / thermal solar air collectors,"Energy Conversion and Management, vol. 41, pp. 861-81, 2000.

[22] Y. Tripanagnostopoulos, et al., "Performance, cost and life-cycle assessment study of hybrid PVT/AIR solar systems,"Progress in Photovoltaics: Research and Applications, vol. 14, no.1, pp. 65-76, 2006.

[23] S.M. Bambrook and Sproul, "Maximising the energy output of a PVT air system,"Solar Energy, vol. 86, no.6, pp. 1857-71, 2012.

[24] J.K. Tonui and Y. Tripanagnostopoulos, "Air-cooled PV/T solar collectors with low cost performance improvements,"Solar Energy, vol. 81, no.4, pp. 498-511, 2007.

[25] M.E.A.Slimani, et al., "Study and modeling of energy performance of a hybrid photovoltaic/thermal solar collector: Configuration suitable for an indirect solar dryer," Energy Conversion and Management, vol. 125, pp. 209-21, 2016.

[26] M. Gholampour \& M. Ameri,"Energy and exergy analyses of Photovoltaic/Thermal flat transpired collectors: Experimental and theoretical study,"Applied Energy, vol. 164, pp. 837-56, 2016. 
[27] C.S. Rajoria, et al., "Exergetic and enviroeconomic analysis of semitransparent PVT array based on optimum air flow configuration and its comparative study,"Solar Energy, vol. 122, pp. 1138-45, 2015.

[28] K.E. Amori, M.A. Abd-AlRaheem, "Field study of various air based photovoltaic/thermal hybrid solar collectors,"Renewable Energy, vol. 63, pp. 402-14, 2014.

[29] C.S. Rajoria, et al., "Exergetic and enviroeconomic analysis of novel hybrid PVT array, "Solar Energy, vol. 88, pp. 110-19, 2013.

[30] K.E. Amori, and H.M.T. Al-Najjar," Analysis of thermal and electrical performance of a hybrid (PV/T) air based solar collector for Iraq,"Applied Energy, vol. 98, pp. 384-95, 2012.

[31] S. Agrawal, et al., "Indoor experimental analysis of glazed hybrid photovoltaic thermal tiles air collector connected in series,"Energy and Buildings, vol. 53, pp. 145-51, 2012.

[32] F. Sarhaddi, et al., "An improved thermal and electrical model for a solar photovoltaic thermal (PV/T) air collector," Applied Energy, vol. 87, pp. 2328-39, 2010.

[33] B. Agrawal \& G.N. Tiwari,"Optimizing the energy and exergy of building integrated photovoltaic thermal (BIPVT) systems under cold climatic conditions,"Applied Energy, vol. 87, pp. 417-26, 2010.

[34] B. Agrawal \& G.N. Tiwari, "Life cycle cost assessment of building integrated photovoltaic thermal (BIPVT) systems,"Energy and Buildings, vol. 42, pp. 1472-81, 2010.

[35] F. Sarhaddi, et al., "Exergetic performance assessment of a solar photovoltaic thermal (PV/T) air collector,"Energy and Buildings, vol. 42, pp. 2184-99, 2010.

[36] A. Fudholi, et al., "Energy and exergy analyses of photovoltaic thermal collector with $\nabla$-groove," Solar Energy, vol. 159, pp. 742-50, 2018.

[37] M.Y. Othman, et al., "Performance analysis of a double-pass photovoltaic/thermal (PV/T) solar collector with CPC and fins. Renewable energy, vol. 30, pp. 2005-2017, 2005.

[38] M.Y. Othman, et al., "Performance studies on a finned double-pass photovoltaic-thermal (PV/T) solar collector". Desalination, vol. 209(1-3), pp. 43-49, 2007.

[39] J.C. Mojumder, et al., "An experimental investigation on performance analysis of air type photovoltaic thermal collector system integrated with cooling fins design," Energy and Buildings, vol. 130:272-285, 2016.

[40] Tabet, et al., "An experimental investigation on performance analysis of air type photovoltaic thermal collector system integrated with cooling fins design," The European Physisical Journal Plus, vol. 131(41), pp. 1-15, 2016.

[41] M. Rosa-Clot, et al., "Experimental photovoltaic-thermal Power Plants based on TESPI panel," Solar Energy, vol. 133, pp. 305-314, 2016.

[42] S. Tiwari and G.N. Tiwari, "Exergoeconomic analysis of photovoltaic-thermal (PVT) mixed mode greenhouse solar dryer," Energy, vol. 114, pp. 155-164, 2016.

[43] B. Das, et al., "Performance analysis of single glazed solar PVT air collector in the climatic condition of NE India," Proceedings: $4^{\text {th }}$ International Electronic Confrence on Entropy and Its Application (ECEA 2017), pp. 1$14,2018$.

[44] A.L. Abdullah, et al., "Numerical analysis of solar hybrid photovoltaic thermal air collector simulation by ANSYS," CFD Letter, vol. 11(2), pp. 1-11, 2019.

Int J Pow Elec \& Dri Syst Vol. 10, No. 4, Dec 2019 : 2029 - 2036 